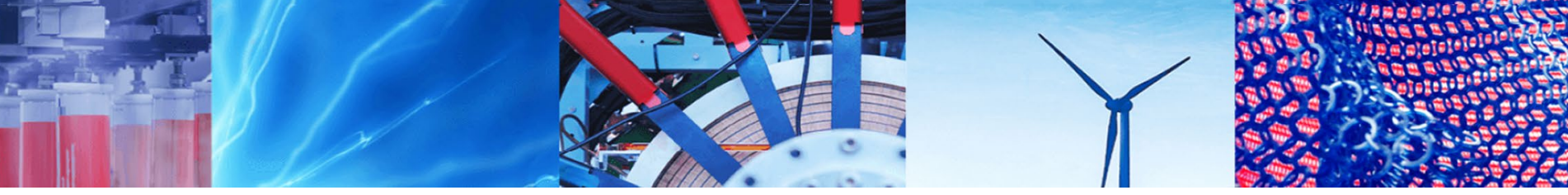

Review Paper

\title{
A critical review on toxicity of cobalt and its bioremediation strategies
}

\author{
Sonia Mahey ${ }^{1,2} \cdot$ Rakesh Kumar $^{3} \cdot$ Manik Sharma $^{4} \cdot \operatorname{Vinod~Kumar~}^{5} \cdot$ Renu Bhardwaj $^{2}$
}

Received: 3 April 2020 / Accepted: 9 June 2020 / Published online: 24 June 2020

(c) Springer Nature Switzerland AG 2020

\begin{abstract}
Accumulation of heavy metals especially cobalt (Co) in agricultural fields and water bodies due to natural as well as anthropogenic factors is major concern. Although it is an important constituent of vitamin $B_{12}$, yet its higher exposure produces significant ramifications in crop plants. It affects biomass and concomitantly reduces crop yield that in turn causes substantial financial loss to farmers. To counter this heavy metal toxicity, the plants have devised mechanisms either to detoxify or accumulate the contaminants. Further, there are various bioremediation strategies that can be used to get rid of $\mathrm{Co}$ from the given medium. Phytostabilisation, phytoextraction, rhizofiltration are some of the techniques used worldwide to reduce cobalt in the fields. This review emphasis upon the uptake, transportation, accumulation of cobalt in plants and discusses the remedial strategies available presently to effectively remove it from mediums like soil and water bodies.
\end{abstract}

Keywords Cobalt $\cdot$ Toxicity $\cdot$ Phytoextraction $\cdot$ Phytostabilisation $\cdot$ Rhizofilteration

\section{Introduction}

Heavy metals (HMs) are the naturally occurring metal elements having atomic number $>20$ with characteristically high atomic density $\left(4 \mathrm{~g} / \mathrm{cm}^{3}\right.$ or five times than that of $\mathrm{H}_{2} \mathrm{O}$ ), and may be toxic at very low concentrations $[1,2]$. Their accumulation in soil is regarded as one of the major culprits for degradation of pedosphere. In nature, HMs are present deeply hidden in the earth as a non-degradable constituent of the earth's crust [3]. But overexploitation of natural resources has given an easy way to these HMs to rise up to the surface of earth. These are present in soil either innately (volcanic activities, weathering of rocks) or added to it by various anthropogenic activities like metal smelting, overuse of fertilizers and industrial waste etc. [4]. Further, it has been found that anthropogenic mediated addition of HMs in atmosphere is almost three times higher as compared to the natural factors [5]. They are discharged in soil and water bodies either in solution or solid forms. In water bodies, they get built up on the sea floor or get adsorbed on to the solid objects [6]. Likewise in soil, HMs keep on piling up because they do not get oxidized by microbes unlikely organic contaminants, hence continue to persist in the soil for long duration of time [7]. They even obstruct the degradation of organic contaminants by inhibiting microbial activity [8]. From soil they slowly leach into underground water to contaminate the water table. The exposure of soil fauna to HMs disturbs their distribution and hence reduces fertility of soil [9]. HMs are known to reduce the growth of sulphate reducing bacteria by denaturing their proteins and inactivating enzymes [10]. Plants growing at such contaminated sites take up these HMs from affected soil-water, and keep on accumulating these HMs. This pile up of HMs in plants gets magnified along the linear network of food chains which may affect human health [11]. Owing to their

$\triangle$ Sonia Mahey, sonia.gndu11@gmail.com | 'Department of Botany, Giani Kartar Singh Memorial College, Urmar, Tanda 144212, India. ${ }^{2}$ Department of Botanical and Environmental Sciences, Guru Nanak Dev University, Amritsar 143005, India. ${ }^{3}$ Department of Botany, Doaba College, Jalandhar 144004, India. ${ }^{4}$ Department of Agriculture, Khalsa College, Amritsar, Punjab 143005, India. ${ }^{5}$ Department of Botany, Government Degree College, Ramban, Jammu 182144, India. 
non-biodegradable nature and longer biological half-life, HMs are more toxic than most other xenobiotics [12]. To break the burgeoning $\mathrm{HM}$ concentrations via food chain, it is necessary to remediate the soil which acts as a sink from where autotrophs start biomagnification (Fig. 1).

HMs ( $\mathrm{Ni}, \mathrm{Cr}, \mathrm{Fe}, \mathrm{Zn}, \mathrm{Mn}$ and $\mathrm{Co}$ ) at low concentrations play an essential role in the growth and development of plants but at concentrations higher than certain threshold levels cause toxicity to the plants [13-15]. Pertaining to their toxic nature, HMs are slurred as severe pollutants [10]. Their toxicity in plants depends upon a number of factors like plant species, form in which metal is present in the soil, soil type, and $\mathrm{pH}$ of the soil etc. [1]. Amongst all the HMs, only a few are essential for the survival of both plants and animals, and that too are required in very low amounts (Table 1). An exposure greater than their permissible limits, leads to cellular and subcellular damage (damage to membranes, mitochondria, chloroplast) due to altered plant metabolism [16]. The HMs manoeuvres various strategies to exert damage at cellular levels. Attributing to their high redox activities and rich coordination chemistry, HMs manage to escape the cellular control checkpoints (homeostasis, compartmentalization, transportation etc.) to bind various subcellular targets that are vital for cell survival. These escaped HMs bring about oxidative damage to biological macromolecules [17]. The most common way of persuading cellular damage by HMs is by inducing oxidative stress by alleviating free radical levels [18]. Reactive oxygen species (ROS) are generated either directly or indirectly by activating ROS generating enzymes [19].

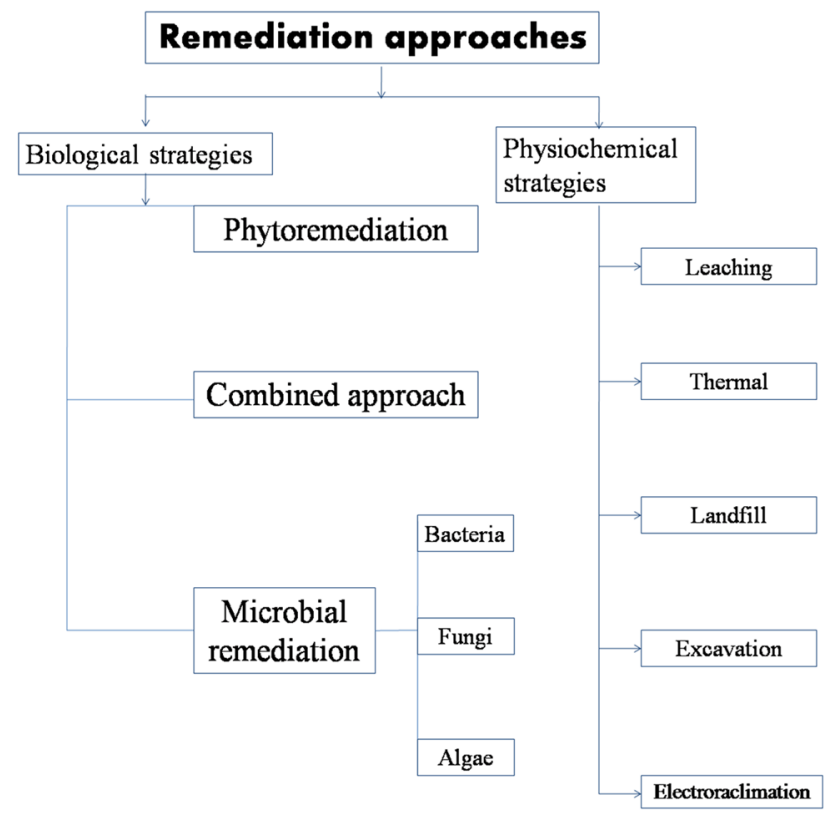

Fig. 1 Classification of remediation techniques used for heavy metals

SN Applied Sciences

APRINGER NATURE journa
Table 1 Limits of metals for water and soil

\begin{tabular}{llll}
\hline S. no. & Heavy metal & $\begin{array}{l}\text { BIS drinking water } \\
\text { specifications } \\
\text { MPL in water (mg/L) }\end{array}$ & Singh et al. (2009) \\
& & MPL in soil (mg/kg) \\
\hline 1. & Manganese & 0.1 & 209 \\
2. & Zinc & 5.0 & 22.1 \\
3. & Chromium & 0.1 & 114 \\
4. & Copper & 2.0 & 56.5 \\
5. & Iron & 1.0 & - \\
6. & Nickel & 0.2 & 27.7 \\
7. & Mercury & 0.001 & - \\
8. & Cadmium & 0.01 & - \\
9. & Arsenic & 0.05 & - \\
10. & Lead & 0.05 & 13.1 \\
11 & Cobalt & - & 15.2 \\
\hline
\end{tabular}

$M P L$, maximum permissible limit; -, Not defined

Depending upon ROS generating potential, the bioactive metals are categorized into two classes, i.e. redox active and non-redox active metals (Fig. 2). The Redox active metals ( $\mathrm{Co}, \mathrm{Cr}, \mathrm{Mn}, \mathrm{Fe}, \mathrm{Cu}$ ) are those that can damage cells by directly generating ROS by up-regulating Haber-Weiss and Fenton reactions $[17,20]$. The non-redox active metals are metals ( $\mathrm{Cd}, \mathrm{Ni}, \mathrm{Hg}, \mathrm{Zn}$ and $\mathrm{Al})$ that damage the cells and their subcellular vitals by indirectly accruing ROS level via glutathione depletion, inhibiting antioxidant enzymes, binding active sulfhydryl groups of proteins and activating ROS producing enzymes such as NADPH oxidase [17, 20, 21]. This review deals with uptake, accumulation, transport, toxicity and remediating strategies of cobalt from contaminated soils and water bodies.

Cobalt (Co) was discovered by Georg Brandt in 1735 $[22,23]$. It is a heavy metal having atomic number 27 and atomic mass 58.93 amu. Co is required as a trace element in both plants and animals. Co exists in numerous inorganic complexes with different oxidation states, but the most common states are +2 and +3 , respectively [24]. Co is a beneficial element for leguminous plants for the growth, metabolism, and development of root nodules [25]. Its importance to the rest of the plant species is still equivocal. It plays an important role in the activities of various enzymes and coenzymes like vitamin $B_{12}$ (cyanocobalamin) [26]. The approximated consumption of Co by humans from food is 5-40 $\mu \mathrm{g} /$ day [27-29] Tolerable limit of $\mathrm{Co}$ in soil for the growth of plants was found to be $0.2-0.5 \mathrm{ppm}$ [30]. Some plant species are able to grow in soil possessing high concentrations of Co up to 4000-10,000 ppm. Co acts as a coenzyme in a number of cellular processes like the fatty acid oxidation and synthesis of DNA. It was found that deficiency of Co in grasses and feedstuffs leads to diseases in ruminants, 
Fig. 2 ROS generation by redox active and non-redox active metals and their mode of cellular damage

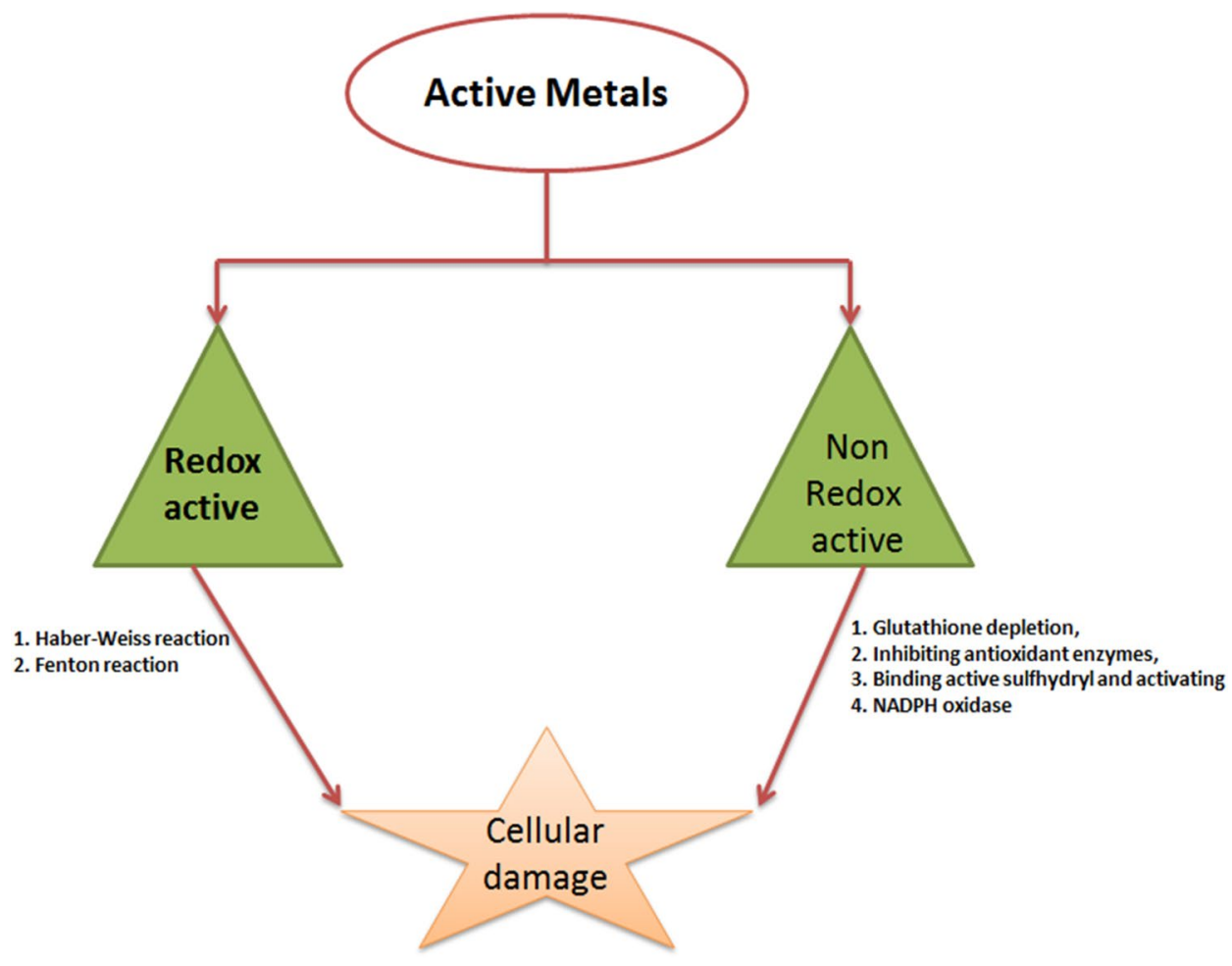

like scaly skin, loss of appetite, anaemia and bone fragility [31, 32]. Toxic concentrations of Co inhibit active transport in plants. Relatively higher concentrations of Co have toxic effects, including leaf fall, inhibition of greening, discoloured veins, premature leaf closure and reduced shoot weight [33]. High concentration of Co leads to numerous dysfunctions in the plant system. These mainly include production of reactive oxygen species (ROS), hydroxyl radical ('OH) generation, formation of hydrogen peroxide $\left(\mathrm{H}_{2} \mathrm{O}_{2}\right)$ radicals, increased MDA, proline content and alteration of antioxidant enzyme activities [34, 35]. ROS generation under Co stress in plants generally causes disturbance in photosystem II and stimulates disruption in electron transport chain [36]. Increased Co content in the soil also reduces photosynthetic pigments and nitrogen metabolism in the plants [37]. Thus, there is a strong need to remediate Co accumulated sites.

The distribution of cobalt is species dependent. Generally leguminous plants contain more Co as compared to grasses and grain crops [38, 39]. Toxic concentrations of cobalt inhibit active transport in plants. Also application of excess of Co has detrimental effects on plant growth and metabolic functions, including leaf necrosis and interveinal chlorosis, inhibition of cellular mitosis and chromosomal damage [40]. Co is also known to inhibit seed germination, root and hypocotyl elongation [41]. Co appears to be toxic when uptake of essential elements like iron and calcium are inhibited $[42,43]$.

\section{Natural source of cobalt}

Cobalt is well known to be siderophile, lithophile as well as chalcophile element [44]. In nature, it is found along with iron, nickel, silver, lead, copper, manganese and also found to exist as carbonates [45]. It also exists in the form of minerals like cobaltite, skutterudite, erythrite, spherocobaltite and heterogenite. It is found abundantly in both sedimentary and igneous rocks. Its average abundance in earth's crust quite low as compared to other HMs, i.e. $25-30 \mathrm{mg} / \mathrm{kg}$ that is higher only to scandium. The ultramafic rocks have higher abundance of Co, i.e. $100 \mathrm{mg} / \mathrm{kg}$. During differentiation of crust from balastic magma, most of the Co combines with ferromagnesian minerals, which is further limited by the number of lattice sites in Fe-Mg. In granite rocks, Co forms tight coherence with magnesium. In open ocean, the Co is present in concentration of about $40 \mathrm{pmol} / \mathrm{kg}$. It has very little mobility [45-47].

\section{Anthropogenic source of cobalt}

About $15 \%$ of the total Co produced worldwide is used for handling and manufacturing of hard metals [48]. Cemented carbide contains $5-30 \%$ of cobalt. Cement industries and carbide tool grinding plants are also responsible for Co leaching $[49,50]$. Industries related to e-waste processing have also been found to release Co above legal threshold levels [51,52]. Polishing disc used in 
diamond polishing is also made up of fine cobalt. It is also a potential source of generating Co dust [53,54]. Pigment and paint industries also use Co as siccative that speeds up the process of drying [55]. Incinerators produce bottom ash which contains Co that leaches to the soil and ground water [56]. Due to mining activities, Co concentration in surrounding soil and water bodies elevates way beyond regional background levels [57]. Mobile batteries, televisions (TVs), liquid crystal display TVs, and computer monitors also contain $\mathrm{Co}$ and become potential source of Co contamination [58-60]. Several cosmetic products are also source of $C o$ as impurities [61]. Many dietary items like chocolate, butter, fish, etc. also contain Co and become source of Co contamination [28, 62, 63]. Many older medicinal practices use Co preparations to treat anaemia, postmenopausal symptoms in women [64-66].

\section{Cobalt uptake, accumulation, transport in plants}

Co is a micronutrient which can be accumulated by plants in very less amount. Co ions may get accrued in the plant parts like fruit, grains and seeds. It is essential to all animals and microorganisms [67]. However, a physiological requirement for $\mathrm{Co}$ has not been demonstrated in higher plants. Co is emitted to the atmosphere in small quantities through activities like coal combustion and mining, processing of Co containing ores, and the production and use of chemicals/fertilizers containing Co salts. Although concentration of Co in plants is normally $0.05-5 \mathrm{mg} / \mathrm{kg}$ dry weight, but this value goes up to $111-245 \mathrm{mg} / \mathrm{kg}$ in plants grown in mining area [68]. Metal ions do not biodegrade. Thus the removal of excess metal ions from polluted sites and their secure sequestration are important for the production of safe food, and viable environment [69]. Uptake, transport and distribution of Co are species dependent and are governed by various mechanistics $[70,71]$. Transport proteins and intracellular affinity binding sites mediate the uptake of Co ions across the plasma membrane. Many classes of proteins have been entailed in heavy metal transport in plants [72]. These include CPxtype ATPases that are involved in the overall metal-ion homeostasis and tolerance in plants, the natural resistance-associated macrophage protein (Nramp), and the cation diffusion facilitator (CDF) family proteins, zinc-iron permease (ZIP) family proteins, etc. [73]. Arabidopsis thaliana Heavy Metal Associated 3 (AtHMA3) protein belonging to the P-type ATPase family, has been found to be involved in heavy metal transport [74]. They demonstrated AtHMA3 is located in the vacuolar membrane of plant. They also found that AtHMA3 improved plant tolerance to $\mathrm{Cd}, \mathrm{Co}$, $\mathrm{Pb}$, and $\mathrm{Zn}$. Studies have demonstrated involvement of
CPX motif in Co ion coordination during transport [75] Moreover, the metal specificity of these ATPases remains unclear. Studies on Synechocystis sp. have shown that a knockout of the encoding ATPases gene leads to increased levels of intracellular $\mathrm{Co}^{2+}$ and reduced $\mathrm{Co}^{2+}$ tolerance [76]. It has also been reported that in higher plants $C o$ ions get bind with the roots, and transferred in the body via passive transport. Co ions enter into the cell through plasma membrane and may be translocated to the whole plant with the help of IRT1 transporters [77].

\section{Toxicity of cobalt in plants}

Due to foolhardy use of fertilizers, wastewater discharge, coal and motor fuel combustion processes, increased mining of the cobalt ore, the concentration of naturally occurring Co has increased [78]. Cobalt is not relegated as an essential element for plants. Nevertheless, it is usually distinguished as a beneficial element having role in certain biochemical and physiological processes of plants. Higher levels of Co in soil causes toxic impacts on plants that are reflected in their morphology as well as physiology [79-81] (Table 2).

Studies also suggested that $\mathrm{Co}$ ions effect the growth of Lemna minor with increase in concentration [82]. Chatterjee and Chatterjee [83] reported that excess Co led to the occurrence of iron ( $\mathrm{Fe}$ ) deficiency in young leaves. Higher Co concentration reduced the biomass, chlorophyll content, and catalase activity, while increased the activities of peroxidase, acid phosphatase, ribonuclease enzymes, and carbohydrate, phosphorus fractions in leaves. Co reduces the translocation of $\mathrm{P}, \mathrm{S}$ and $\mathrm{Cu}$ and drops the transpiration rate and water potential in the leaves of cauliflower [1]. Application of $5 \mathrm{mM}$ Co resulted in reduction in seedling growth due to chlorosis of the younger leaves [84]. Higher concentrations $\left(10^{-2} \mathrm{M}\right)$ of $\mathrm{Cr}$, Co induced reduction in seed germination rate and radicle growth, while lower concentrations $\left(10^{-6}-10^{-4} \mathrm{M}\right)$ raised sugar and chlorophyll contents [85].

Effect of $\mathrm{Co}^{2+}, \mathrm{Ni}^{2+}$ and $\mathrm{Cd}^{2+}$ on growth and metabolic parameters in cabbage produced visible symptoms like chlorosis. $\mathrm{Co}^{2+}$ treated plants showed purple colouration along leaf margins. Equimolar concentrations of $\mathrm{Cd}^{2+}$ and $\mathrm{Ni}^{2+}$ inhibited growth of plants causing severe symptoms of toxicity. Excess concentrations of the three metals lead to decrease in chlorophyll content, uptake and translocation of $\mathrm{Fe}$ in leaves and reduced proline activity [86]. The cobalt toxicity on growth and metabolism of tomato plants was studied in sand medium at five levels of concentration, i.e. $0,0.05,0.1,0.4$ and $0.5 \mathrm{mM}$. Strong effects of cobalt on tomato were observed at $0.5 \mathrm{mM}$ after 3 days of metal supply. The prominent symptoms 
Table 2 Effect of cobalt on growth parameters, photosynthetic pigments and antioxidant enzymes

\begin{tabular}{|c|c|c|c|c|c|c|}
\hline Family & Plant species & $\begin{array}{l}\text { Cobalt concentra- } \\
\text { tion }\end{array}$ & Mode of treatment & $\begin{array}{l}\text { Treat- } \\
\text { ment } \\
\text { days }\end{array}$ & $\begin{array}{l}\text { Effects on growth } \\
\text { parameters }\end{array}$ & References \\
\hline \multicolumn{7}{|c|}{ Effect of Co on growth parameters } \\
\hline \multirow[t]{4}{*}{ Brassicaceae } & Raphnus sativus & $250 \mathrm{mg} / \mathrm{kg}$ & Soil & 30 & $\begin{array}{l}\text { Decrease in root } \\
\text { length, shoot } \\
\text { length and leaf } \\
\text { area }\end{array}$ & $\begin{array}{l}\text { Jayakumar et al. } \\
\text { (2007) }\end{array}$ \\
\hline & Brassica juncea & $2 \times 10^{-3} \mathrm{M}$ & Soil & 30 & $\begin{array}{l}\text { Reduction in shoot, } \\
\text { root growth and } \\
\text { number of leaves }\end{array}$ & Arora et al. (2012) \\
\hline & Brassica juncea & $100 \mu \mathrm{M}$ & Petri dishes & 6 & $\begin{array}{l}\text { Reduction in shoot } \\
\text { and root length, } \\
\text { seedling length, } \\
\text { fresh and dry } \\
\text { weight of seed- } \\
\text { lings }\end{array}$ & $\begin{array}{l}\text { Karuppanapandian } \\
\text { and Kim (2013) }\end{array}$ \\
\hline & Brassica campestris & $500 \mu \mathrm{M}$ & Sand & 43 & $\begin{array}{l}\text { Shortening of inter- } \\
\text { nodes, reduction } \\
\text { in the size of leaves }\end{array}$ & Sinha et al. (2012) \\
\hline \multirow[t]{5}{*}{ Fabaceae } & Vigna radiata & $250 \mathrm{mg} / \mathrm{kg}$ & Soil & 30 & $\begin{array}{l}\text { Decrease in root } \\
\text { length, shoot } \\
\text { length, number of } \\
\text { nodules, root dry } \\
\text { weight and shoot } \\
\text { dry weight }\end{array}$ & Jaleel et al. (2009) \\
\hline & Phaseolus aureus & $400 \mu \mathrm{M}$ & Soil & 45 & $\begin{array}{l}\text { Reduction in size, } \\
\text { growth of leaves } \\
\text { and internodes } \\
\text { length }\end{array}$ & Tewari et al. (2002) \\
\hline & Glycine max & $150 \mathrm{mM}$ & Soil & 12 & $\begin{array}{l}\text { Reduction in seed } \\
\text { percentage germi- } \\
\text { nation, root and } \\
\text { shoot growth, }\end{array}$ & Imtiyaz et al. (2014) \\
\hline & Cicer arietinum & 400 ppm & $\begin{array}{l}\text { Before sowing in } \\
\text { pots }\end{array}$ & 30 & $\begin{array}{l}\text { Reduction in plant } \\
\text { growth, fresh } \\
\text { and dry weight, } \\
\text { biomass and pod } \\
\text { formation }\end{array}$ & Khan and Khan (2010) \\
\hline & Medicago sativa & $0.01 \mathrm{M}$ & Through seeds & 90 & $\begin{array}{l}\text { Reduction in shoot } \\
\text { and root length, } \\
\text { shoot and root } \\
\text { fresh and dry } \\
\text { weight, leaf num- } \\
\text { ber, leaf fresh and } \\
\text { dry weight, and } \\
\text { branches number }\end{array}$ & Zeid et al. (2013) \\
\hline \multirow[t]{3}{*}{ Solanaceae } & Solanum nigrum & $\begin{array}{l}{ }^{57} \mathrm{Co} \text { ( } \% \text { of label } \\
\text { added to nutrient } \\
\text { medium) }\end{array}$ & $\begin{array}{l}\text { Cut xylem of flap, } \\
\text { midrib }\end{array}$ & 55 & $\begin{array}{l}\text { Reduction in root, } \\
\text { stem and leaves }\end{array}$ & Wei et al. (2014) \\
\hline & $\begin{array}{l}\text { Lycopersicon escu- } \\
\text { lentum }\end{array}$ & 30 mg/L & Nutrient solution & 30 & $\begin{array}{l}\text { Decrease in plant } \\
\text { height, length of } \\
\text { root, stem and } \\
\text { leaves }\end{array}$ & $\begin{array}{l}\text { Moreno-Caselles et al. } \\
\quad(1997)\end{array}$ \\
\hline & $\begin{array}{l}\text { Lycopersicon escu- } \\
\text { lentum }\end{array}$ & $0.5 \mathrm{mM}$ & Soil & 40 & $\begin{array}{l}\text { Reduction in } \\
\text { growth, biomass, } \\
\text { root and shoot } \\
\text { growth }\end{array}$ & Gopal et al. (2003) \\
\hline Lemnaceae & Lemna minor & $100 \mu \mathrm{M}$ & Soil & 7 & $\begin{array}{l}\text { reduction in relative } \\
\text { growth rates }\end{array}$ & Sree et al. (2015) \\
\hline
\end{tabular}


Table 2 (continued)

\begin{tabular}{|c|c|c|c|c|c|c|}
\hline Family & Plant species & $\begin{array}{l}\text { Cobalt concentra- } \\
\text { tion }\end{array}$ & Mode of treatment & $\begin{array}{l}\text { Treat- } \\
\text { ment } \\
\text { days }\end{array}$ & $\begin{array}{l}\text { Effects on growth } \\
\text { parameters }\end{array}$ & References \\
\hline \multirow[t]{2}{*}{ Poaceae } & Maize cultivars & $25 \mathrm{ppm}$ & Soil & 80 & $\begin{array}{l}\text { Reduction in plant } \\
\text { height, number } \\
\text { of leaves, root } \\
\text { and shoot length, } \\
\text { and fresh and dry } \\
\text { matter }\end{array}$ & $\begin{array}{l}\text { Gad and El-Metwally } \\
\text { (2015) }\end{array}$ \\
\hline & Barley & $100 \mathrm{mg} / \mathrm{kg}$ & Soil & 21 & Dry matter reduced & $\begin{array}{l}\text { Nessim and Abdalla } \\
\text { (2008) }\end{array}$ \\
\hline Bacillariaceae & Nitzschia perminuta & 3 ppm & Petri dishes & 11 & Reduction in growth & El-Sheekh et al. (2003) \\
\hline Selenastraceae & $\begin{array}{l}\text { Monoraphidium } \\
\text { minutum }\end{array}$ & 3 ppm & Petri dishes & 11 & Reduction in growth & El-Sheekh et al. (2003) \\
\hline \multicolumn{7}{|c|}{ Effect of Co on photosynthetic pigments } \\
\hline \multirow[t]{2}{*}{ Lemnaceae } & Lemna minor & $100 \mu \mathrm{M}$ & Soil & 7 & $\begin{array}{l}\text { chlorophyll content } \\
\text { and photosyn- } \\
\text { thetic efficiency } \\
\text { reduced }\end{array}$ & Sree et al. (2015) \\
\hline & Lemna minor & $1 \mathrm{mM}$ & Petri dishes & 3 & $\begin{array}{l}\text { Decrease in chlo- } \\
\text { rophyll } a \text { and } \\
\text { chlorphyll } b\end{array}$ & Begovic et al. (2016) \\
\hline \multirow[t]{2}{*}{ Fabaceae } & Cicer arietinum & $250 \mathrm{mM}$ & Pots & 60 & $\begin{array}{l}\text { Chlorophyll content } \\
\text { and stomatal con- } \\
\text { ductance, intercel- } \\
\text { lular } \mathrm{CO}_{2} \text { conc. and } \\
\text { net photosynthetic } \\
\text { rate }\end{array}$ & Ali et al. (2010) \\
\hline & Cicer arietinum & 400 ppm & $\begin{array}{l}\text { Before sowing in } \\
\text { pots }\end{array}$ & 30 & $\begin{array}{l}\text { Reduction in chloro- } \\
\text { phyll content }\end{array}$ & Khan and Khan (2010) \\
\hline Selenastraceae & $\begin{array}{l}\text { Monoraphidium } \\
\text { minutum }\end{array}$ & 3 ppm & Petri dishes & 11 & $\begin{array}{l}\text { Reduction in chloro- } \\
\text { phyll a and b and } \\
\text { carotenoids }\end{array}$ & El-Sheekh et al. (2003) \\
\hline Bacillariaceae & Nitzschia perminuta & 3 ppm & Petri dishes & 11 & $\begin{array}{l}\text { Reduction in chloro- } \\
\text { phyll a and b and } \\
\text { carotenoids }\end{array}$ & El-Sheekh et al. (2003) \\
\hline Brassicaceae & Brassica juncea & $100 \mu \mathrm{M}$ & Petri dishes & 6 & $\begin{array}{l}\text { Reduction in total } \\
\text { chlorophyll con- } \\
\text { tent }\end{array}$ & $\begin{array}{l}\text { Karuppanapandian } \\
\text { and Kim (2013) }\end{array}$ \\
\hline \multicolumn{7}{|c|}{ Effect of Co on antioxidant enzymes } \\
\hline Brassicaceae & Brassica juncea & $2 \times 10^{-3} \mathrm{M}$ & Soil & 30 & $\begin{array}{l}\text { Enhancement in } \\
\text { activities of CAT, } \\
\text { GR, APOX, DHAR } \\
\text { and MDHAR }\end{array}$ & Arora et al. (2012) \\
\hline Fabaceae & Cicer arietinum & $250 \mathrm{mM}$ & Pots & 60 & $\begin{array}{l}\text { Reduction of CAT, } \\
\text { POX, GR and SOD }\end{array}$ & Ali et al. (2010) \\
\hline Lemanaceae & Lemna minor & $1 \mathrm{mM}$ & Petri dishes & 3 & $\begin{array}{l}\text { Reduction in SOD } \\
\text { activity }\end{array}$ & Begovic et al. (2016) \\
\hline
\end{tabular}


Table 2 (continued)

\begin{tabular}{|c|c|c|c|c|c|c|}
\hline Family & Plant species & $\begin{array}{l}\text { Cobalt concentra- } \\
\text { tion }\end{array}$ & Mode of treatment & $\begin{array}{l}\text { Treat- } \\
\text { ment } \\
\text { days }\end{array}$ & $\begin{array}{l}\text { Effects on growth } \\
\text { parameters }\end{array}$ & References \\
\hline \multirow[t]{2}{*}{ Brassicaceae } & Brassica juncea & $100 \mu \mathrm{M}$ & Petri dishes & 6 & $\begin{array}{l}\text { Enhancement in } \\
\text { contents of pro- } \\
\text { line, malondialde- } \\
\text { hyde, superoxide } \\
\text { anion and hydro- } \\
\text { gen peroxide, and } \\
\text { reduction in the } \\
\text { activities of CAT, } \\
\text { POX and SOD. }\end{array}$ & $\begin{array}{l}\text { Karuppanapandian } \\
\text { and Kim (2013) }\end{array}$ \\
\hline & Brassica campestris & $500 \mu \mathrm{M}$ & Sand & 43 & $\begin{array}{l}\text { Increase in the } \\
\text { activities of APX, } \\
\text { POX }\end{array}$ & Sinha et al. (2012) \\
\hline
\end{tabular}

were appearance of chlorosis on young leaves followed by necrosis and withering. Supererogatory levels of $\mathrm{Co}_{0}$ significantly affected biomass, concentrations of various minerals like $\mathrm{P}, \mathrm{S}$ and $\mathrm{Fe}$, and diminished level of chlorophyll $a$ and $b$, DNA, starch as well as reducing and nonreducing sugar levels. Increased concentrations of metal also inhibited the activity of antioxidative enzymes like catalase, peroxidase, ribonuclease and acid phosphatase [87]. Binary effect Co with $(0,20$ and $40 \mathrm{mg} / \mathrm{kg}$ soil) and $\mathrm{Ni}$ with $(0,25$ and $50 \mathrm{mg} / \mathrm{kg})$ was studied on growth, yield, content of micro- and macronutrients and anthocyanins of Hibiscus sabdariffa $\mathrm{L}$. The results revealed that $\mathrm{Co}$ and $\mathrm{Ni}$ in combination of $20+25 \mathrm{mg} / \mathrm{kg}^{-1}$ significantly increased plant height, number of branches as well as dry and fresh weights. The lower doses of Co showed synergistic effect on $\mathrm{Ni}, \mathrm{Mn}, \mathrm{Zn}$ and $\mathrm{Cu}$ [88].

Some studies reported that increased concentration $(10,50,100,150 \mathrm{mM})$ of heavy metals $(\mathrm{Ni}, \mathrm{Co}, \mathrm{Fe})$ decreased the rate of seed germination, root length, shoot length, protein and phenolics content in broad beans (Vicia faba L.). The metal toxicities of various metals studied were found in the order $\mathrm{Co}>\mathrm{Ni}>\mathrm{Fe}$. The workers also inferred that bean is a metal resistant plant which has contrived various mechanisms such as denovo synthesis of antistress protein or mitigation of ROS by enhanced phenolic production to combat metal stress [89]. The phytoremediating ability of Eleusine indica (grass) was studied in $\mathrm{Cu}$, $\mathrm{Cd}, \mathrm{Cr}, \mathrm{Co}$ and $\mathrm{Pb}$ laden soils. The preliminary levels of $\mathrm{Cu}$, $\mathrm{Cd}, \mathrm{Cr}, \mathrm{Co}$ and $\mathrm{Pb}$ in soil, root and shoot of the grass were: soils: $104.5,5.1,36.4,13.3,14.4 \mu \mathrm{g} / \mathrm{g}$; root: $164.2,4.3,153.9$, 11.5 and $24.7 \mu \mathrm{g} / \mathrm{g}$ and shoot of the grass were: $111.5,2.9$, $51.2,11.1$, and $60.7 \mu \mathrm{g} / \mathrm{g}$, respectively. Enrichment coefficient (EC) and translocation factor (TF) were calculated to estimate the phytoextraction ability of $E$. indica. They found that $\mathrm{Cu}, \mathrm{Cr}$ and $\mathrm{Pb}$ had the highest $\mathrm{EC}$ of $1.07,1.41$ and 4.22 , respectively [90].
The possible mechanism of actions of cobalt in plants, and proposed way of action of oxidizing and chelating agents is presented in Figs. 3 and 4.

\section{Bioremediation strategies}

Bioremediation is an innovative and inventive biological approach that explores potential of microorganisms and plants to reduce and remediate soil and water bodies from toxic chemicals [91, 92]. Bioremediation explores potential of microorganisms to remediate given medium viz., Bacillus spp. and Pseudomonas aeruginosa are used to remove $\mathrm{Zn}$ and $\mathrm{Cu}$ [93].

\subsection{Phytoremediation}

Phytoremediation is the direct use of green plants and their associated microorganisms to decrease or stabilize pollution in soils, sediments, ground water, surface water and sludge [94]. Here, metal tolerant and hyper-accumulating plant-microbe interactions are also explored for mobilization of metals $[95,96]$. First used in 1990, it is a natural process used to remediate the contaminants, and has gained a lot of consideration during the last few years, on account of its being cost effective and promising technique [97]. A number of phytoremediation techniques are available, but in the following section only those are discussed which are involved in remediation of $\mathrm{Co}$.

\subsubsection{Phytostabilization}

It is method of establishment of metal tolerant vegetation cover over contaminated area in order to immobilise contaminants within rhizosphere zone of plant. Growth of vegetation on contaminated area restricts dispersion 
Fig. 3 Possible mechanisms of cobalt in plants
Fig. 4 Possible mechanism of action of oxidizing and chelating agents

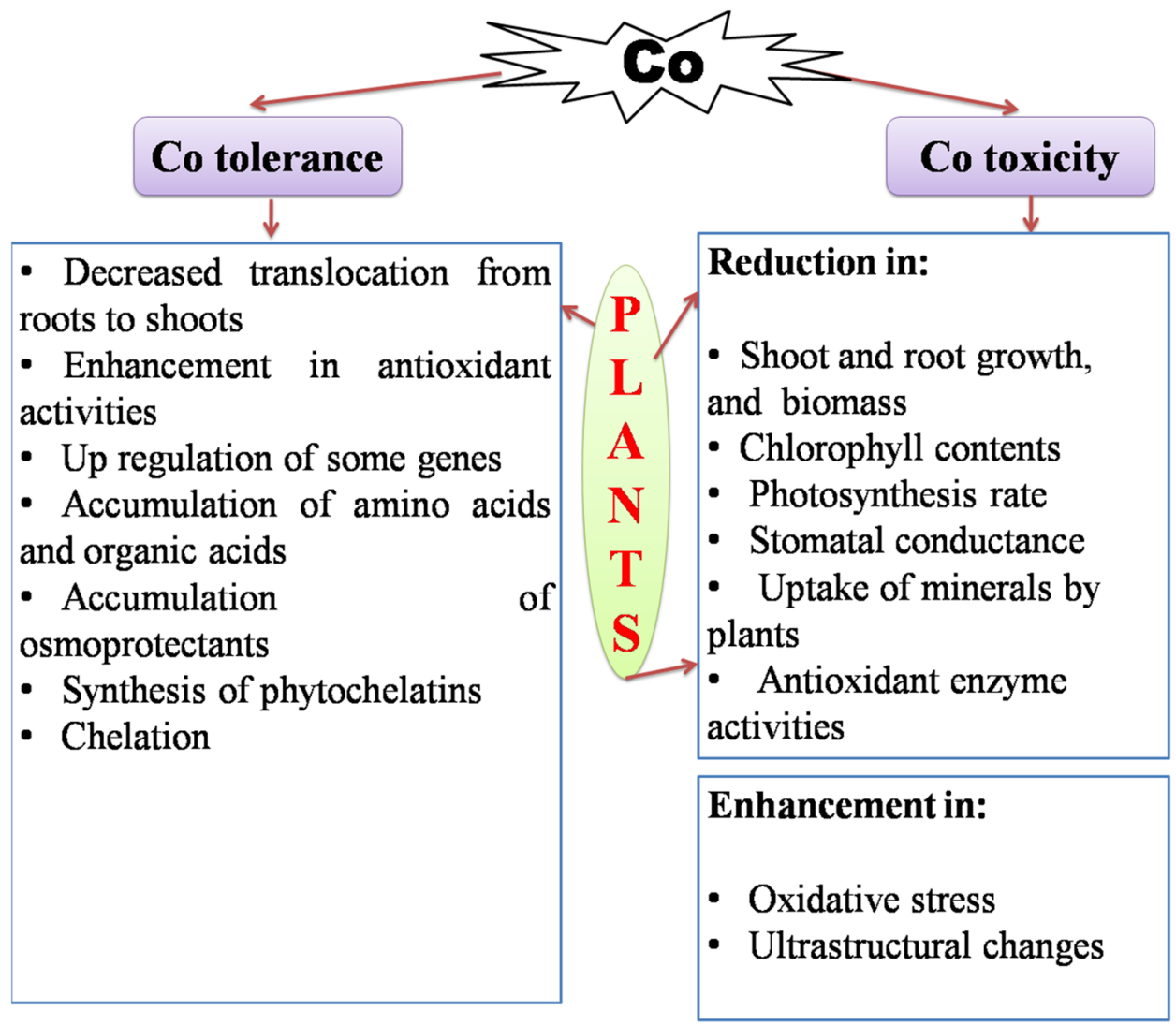

- Synthesis of phytochelatins

- Chelation

Enhancement in:

- Oxidative stress

- Ultrastructural changes

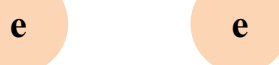

\section{e}

A

Reducing agent

Oxidized

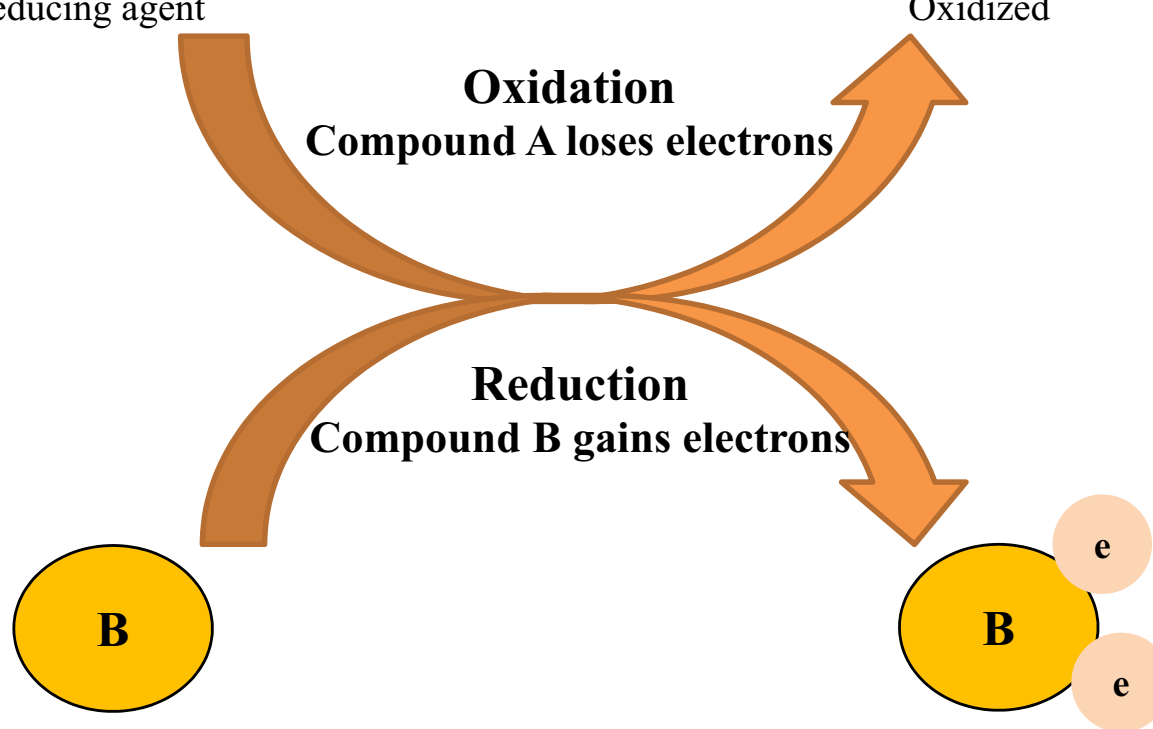

Oxidizing agent 
of metal laden soil particles by air or water. Further, the microbes growing in rhizosphere immobilize the contaminants by precipitation or adsorption mechanism [98, 99]. Moreover, retention or immobilisation of HMs in soil is also dependent upon $\mathrm{pH}$ of soil as most of the adsorption sites are $\mathrm{pH}$ dependent. An inverse relationship between increase in $\mathrm{pH}$ (from acidic to alkaline) and leaching of Co was observed where, increasing $\mathrm{pH}$ value from 1 to 3 , leaching of Co was significantly decreased up to $30 \%$. This showed that $\mathrm{Co}$ is weakly bound in mineral phase as compared to other HMs [100].

\subsubsection{Phytoextraction}

It involves the removal of contaminants from soil or water body through roots of plants and their accumulation in shoot system. Thus, contaminant is removed from the medium [101]. This technique is usually employed when phytostabilization is not possible. The success of phytoextraction is dependent upon two factors, i.e. biomass production (where metal is stored) and metal bioconcentration factor (ratio of contaminant in shoot by its concentration in medium). There are more than four hundred plants which are reported as hyperaccumulators. A study by Malik et al. [102] presented Alysssum murale as potential hyperaccumulator of $\mathrm{Co}$. A. murale accumulated sixty times more Co, i.e. $1320 \mathrm{mg} \mathrm{Co} / \mathrm{kg}$ dry weight as compared to Brassica juncea in Co enriched soil. Thlapsi caerulescens is another hyperaccumulator of $\mathrm{Zn}$ also used for phytoextraction of Co. Lycopersicon esculentum was also shown to act as accumulator of Co with accumulating Co in all above ground plant parts except flowers and fruits [103].

\subsubsection{Rhizofiltration}

It is the technique exclusive used in water bodies. It explores potential of plant roots to take up and get rid of contaminants from water body [104]. The contaminants are absorbed and precipitated in the roots from medium. The plants are first raised hydroponically and then they are transferred to the given contaminated water body [105]. Epipremnum is successfully used for rhizofiltration of Co. Plant showed a bioconcentration factor of 10.69 for Co [106]. Prajapati et al. [107] have effectively used Pistia stratiotes in their experimental set up to remove Co from water medium.

\section{Conclusion}

Increased contamination of cobalt in the agricultural fields and water bodies is alarming. A number of remedial procedures are available to remediate our contaminated sites. But the interaction of metals sometimes, makes one or other metal immobile that limits use of bioremediation strategies. So, new techniques and strategies should be continuously devised to reduce limitations of bioremediation procedures.

Acknowledgements Authors are thankful to University Grants Commission, New Delhi for research fellowship granted (vide Grant No. F.14-2(SC)/2010(SA-III) to the first author Sonia.

\section{Compliance with ethical standards}

Conflict of interest All authors declare that they have no conflict ofinterest.

\section{References}

1. Nagajyoti PC, Lee KD, Sreekanth TVM (2010) Heavy metals, occurrence and toxicity for plants: a review. Environ Chem Lett 8:199-216

2. Tchounwou PB, Yedjou CG, Patlolla AK, Sutton DJ (2012) Heavy metals toxicity and the environment. Mol Clin Environ Toxicol 101:133-164

3. Bucker-Neto L, Paiva ALS, Machado RD, Arenhart RA, MargisPinheiro M (2017) Interactions between plant hormones and heavy metals responses. Gen Mol Biol 40:373-386

4. Shahzad B, Mohsin T, Zhao C, Rehman A, Cheema SA, Sharma A, Song H, Rehman S, Zhaorong D (2018) Role of 24-epibrassinolide (EBL) in mediating heavy metal and pesticide induced oxidative stress in plants: a review. Ecotoxicol Environ Saf 147:935-944

5. Sposito G, Page AL (1984) Cycling of metal ions in the soil environment. Met lon Biol Syst 18:287-332

6. Ciszewski D, Grygar TM (2016) A review of flood-related storage and remobilization of heavy metal pollutants in river systems. Water Air Soil Pollut 227:1-19

7. Wuana RA, Okieimen FE (2011) Heavy metals in contaminated soils: a review of sources, chemistry, risks and best available strategies for remediation. Int Sch Res Not 2011:1-20

8. Maslin P, Maier RM (2000) Rhamnolipid-enhanced mineralization of phenanthrene in organic-metal Co-contaminated soils. Bioremed J 4:295-308

9. Uwizeyimana H, Wang M, Chen W, Khan K (2017) The eco-toxic effects of pesticide and heavy metal mixtures towards earthworms in soil. Environ Toxicol Pharmacol 55:20-29

10. Guo J, Kang Y, Feng Y (2017) Bioassessment of heavy metal toxicity and enhancement of heavy metal removal by sulfatereducing bacteria in the presence of zero valent iron. J Environ Manag 203:278-285

11. Kobielska PA, Howarth AJ, Farha OK, Nayak S (2018) Metal organic frameworks for heavy metal removal from water. Coord Chem Rev 358:92-107

12. Ramachandra TV, Sudarshan PB, Mahesh MK, Vinay S (2018) Spatial patterns of heavy metal accumulation in sediments and macrophytes of Bellandur wetland, Bangalore. J Environ Manag 206:1204-1210

13. Shah FUR, Ahmad N, Masood KR, Peralta-Videa JR, Ahmad FU (2010) Heavy metal toxicity in plants. In: Ashraf M, Ozturk M, Ahmad M (eds) Plant adaptation and phytoremediation. Springer, Dordrecht, pp 71-97 


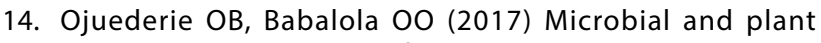
assisted bioremediation of heavy metal polluted environments a review. Int J Environ Res Public Health 14:1504

15. Shahid M, Dumat C, Khalid S, Schreck E, Xiong T, Niazi NK (2017) Foliar heavy metal uptake, toxicity and detoxification in plants: a comparison of foliar and root metal uptake. J Hazard Mater 325:36-58

16. Kim YH, Khan AL, Lee IJ (2016) Silicon: a duo synergy for regulating crop growth and hormonal signaling under abiotic stress conditions. Crit Rev Biotechnol 36:1099-1109

17. Valko M, Morris H, Cronin MTD (2005) Metals, toxicity and oxidative stress. Curr Med Chem 12:1161-1208

18. Jalmi SK, Bhagat PK, Verma D, Noryang S, Tayyeba S, Singh K, Sharma D, Sinha AK (2018) Traversing the links between heavy metal stress and plant signaling. Front Plant Sci 9:1-21

19. Cuypers A, Smeets K, Vangronsveld J (2009) Heavy metal stress in plants. In: Hirt $\mathrm{H}$ (ed) Plant stress biology: from genomics to systems biology. Wiley-VCHVerlag GmbH \& Co. KGaA, Weinheim, pp 161-178. ISBN ISBN 978-3-527-32290-9

20. Jozefczak M, Remans T, Vangronsveld J, Cuypers A (2012) Glutathione is a key player in metal-induced oxidative stress defenses. Int J Mol Sci 13:3145-3175

21. Bielen A, Remans T, Vangronsveld J, Cuypers A (2013) The influence of metal stress on the availability and redox state of ascorbate, and possible interference with its cellular functions. Int J Mol Sci 14:6382-6413

22. Weeks ME (1942) Discovery of the elements. J Chem Educ Easton, PA

23. Lide DR (1991) CRC handbook of chemistry and physics. Ed. 72. CRC, Boca Raton

24. Kobayashi M, Shimizu S (1999) Cobalt proteins. Eur J Biochem 261:1-9

25. Tsyganov VE, Tsyganova AV, Gorshkov AP, Seliverstova EV, Kim VE, Chizhevskaya EP, Belimov AA, Serova TA, Ivanova KA, Kulaeva OA, Kusakin PG (2020) Efficacy of a plant-microbe system: Pisum sativum (L.) cadmium-tolerant mutant and rhizobium leguminosarum strains, expressing pea metallothionein genes PsMT1 and PsMT2, for cadmium phytoremediation. Front Microbiol 11:15

26. Adolfo FR, do Nascimento PC, Bohrer D, de Carvalho LM, Viana C, Guarda A, Colim AN, Mattiazzi P (2016) Simultaneous determination of cobalt and nickel in vitamin $B_{12}$ samples using high resolution continuum source atomic absorption spectrometry. Talanta 147:241-245

27. Kim JH, Gibb HJ, Howe PD (2006) Cobalt and inorganic cobalt compounds. Concise and international chemical assessment document; 69 . WHO Library Cataloguing in publication data

28. Hokin B, Adams M, Ashton J, Louie H (2004) Comparison of the dietary cobalt intake in three different Australian diets. Asia Pac J Clin Nutr 13:289-291

29. Tvermoes BE, Unice KM, Paustenbach DJ, Finley BL, Otani JM, Galbraith DA (2014) Effects and blood concentrations of cobalt after ingestion of $1 \mathrm{mg} / \mathrm{d}$ by human volunteers for 90 d. Am J Clin Nutr 99:632-646

30. Bennet WF (1994) Plant nutrient utilization and diagnostic plant symptoms. In: Bennett WF (ed) Nutrient deficiencies and toxicities in crop plants. APS Press, St. Paul, pp 1-7

31. Smart ME, Gudmundson J, Christensen DA (1981) Trace mineral deficiencies in cattle: a review. Can Vet J 22:372-376

32. Lee HJ (1975) Trace elements in soil-plant-animal systems animal production. In: Nicholas DJD, Egan AR (eds) Trace elements in soil-plant-animal systems. Academic Press, New York, pp 39-54

33. Sonia Thukral AK (2014) Effects of macro- and nano-cobalt oxide particles on barley seedlings and remediation of cobalt chloride toxicity using sodium hypochlorite. Int J Plant Soil Sci 3:751-762

34. Tewari RK, Kumar P, Sharma PN, Bisht SS (2002) Modulation of oxidative stress responsive enzymes by excess cobalt. Plant Sci 162:381-388

35. Azarakhsh MR, Asrar Z, Mansouri H (2015) Effects of seed and vegetative stage cysteine treatments on oxidative stress response molecules and enzymes in Ocimum basilicum L. under cobalt stress. J Soil Sci Plant Nutr 15:651-662

36. Begovic L, Mlinaric S, Dunic JA, Katanic Z, Loncaric Z, Lepedus H, Cesar V (2016) Responses of Lemna minor L. to short term cobalt exposure the effect on photosynthetic electron transport chain and induction of oxidative damage. Aqua Toxicol 175:117-126

37. Ali B, Hayat S, Hayat Q, Ahmad A (2010) Cobalt stress affects nitrogen metabolism, photosynthesis and antioxidant system in chickpea (Cicer arietinum L.). J Plant Inter 5:223-231

38. Sauchelli V (1969) Trace elements in agriculture. Van Norstrand Reinhold, New York

39. Sillanpää M, Jansson H (1992) Status of cadmium, lead, cobalt and selenium in soils and plants of thirty countries (No. 65). Food and Agriculture Organisation

40. Wendling LA, Kirby JK, Mclaughlin MJ (2009) Aging effects on cobalt availability in soils. Environ Toxicol Chem 28:1609-1617

41. Thukral AK, Kaur P (1987) Effect of some trace elements of polluted waters on germination of Cyamopsis tetragonoloba Taub. Ind J Ecol 14:185-188

42. Wallace A, Sufi SM, Romney EM (1971) Regulation of heavy metal uptake and responses in plants. Rec Adv Plant Nutr 2:547-558

43. Terry N (1981) Physiology of trace element toxicity and its relation to iron stress. J Plant Nutr 3:561-578

44. Poznanović Spahić MM, Sakan SM, Glavaš-Trbić BM, Tančić PI, Škrivanj SB, Kovačević JR, Manojlović DD (2019) Natural and anthropogenic sources of chromium, nickel and cobalt in soils impacted by agricultural and industrial activity (Vojvodina, Serbia). J Environ Sci Health Part A 54:219-230

45. Graedel TE, Gunn G, Espinoza LT (2014) Metal resources, use and criticality. Crit Metals Handb 6:1

46. McDonough WF (2014) Compositional model for the Earth's core. In: Holland HD, Turekian KK (eds) Treatise on geochemistry, 2nd edn. Elsevier, Oxford, pp 559-577

47. Palme H, Lodders $K$, Jones A (2014) Solar system abundances of the elements. In: Holland HD, Turekian KK (eds) Treatise on geochemistry, 2nd edn. Elsevier, Oxford, pp 15-36

48. Klasson M, Bryngelsson IL, Pettersson C, Husby B, Arvidsson $\mathrm{H}$, Westberg H (2016) Occupational exposure to cobalt and tungsten in the Swedish hard metal industry: air concentrations of particle mass, number, and surface area. Ann Occup Hyg 60:684-699

49. Abraham JL, Hunt A (1995) Environmental contamination by cobalt in the vicinity of a cemented tungsten carbide tool grinding plant. Environ Res 69:67-74

50. Lu H, Wei F, Tang J, Giesy JP (2016) Leaching of metals from cement under simulated environmental conditions. J Environ Manag 169:319-327

51. Nnorom IC, Osibanjo O (2009) Heavy metal characterization of waste portable rechargeable batteries used in mobile phones. Int J Environ Sci Technol 6:641-650

52. Lim SR, Schoenung JM (2010) Human health and ecological toxicity potentials due to heavy metal content in waste electronic devices with flat panel displays. J Hazard Mater 177:251-259

53. Van den Oever R, Roosels D, Douwen M, Vanderkeel J, Lahaye $D$ (1990) Exposure of diamond polishers to cobalt. Ann Occup Hyg 34:609-614 
54. Leyssens L, Vinck B, Van Der Straeten C, Wuyts F, Maes L (2017) Cobalt toxicity in humans-a review of the potential sources and systemic health effects. Toxicology 387:43-56

55. Christensen JM, Poulsen OM (1994) A 1982-1992 surveillance programme on Danish pottery painters. Biological levels and health effects following exposure to soluble or insoluble cobalt compounds in cobalt blue dyes. Sci Total Environ 150:95-104

56. Feng S, Wang X, Wei G, Peng P, Yang Y, Cao Z (2007) Leachates of municipal solid waste incineration bottom ash from Macao: heavy metal concentrations and genotoxicity. Chemosphere 67:1133-1137

57. Cheyns K, Nkulu CBL, Ngombe LK, Asosa JN, Haufroid V, De Putter T, Nemery B (2014) Pathways of human exposure to cobalt in Katanga, a mining area of the DR Congo. Sci Total Environ 490:313-321

58. Kluger N, Raison-Peyron N, Guillot B (2009) Contact dermatitis to nickel related to cellular phone use. Presse Med (Paris, France: 1983), 38: 1694-1696

59. Lee DY, Yang JM (2010) Preauricular eczema: a sign of cellular phone dermatitis. Clin Exp Derma 35:201-202

60. Aquino M, Mucci T, Chong M, Lorton MD, Fonacier L (2013) Mobile phones: potential sources of nickel and cobalt exposure for metal allergic patients. Ped Aller Immunol Pulmonol 26:181-186

61. Bocca B, Pino A, Alimonti A, Forte G (2014) Toxic metals contained in cosmetics: a status report. Regul Toxicol Pharmacol 68:447-467

62. Arnich N, Sirot V, Rivière G, Jean J, Noël L, Guérin T, Leblanc JC (2012) Dietary exposure to trace elements and health risk assessment in the 2nd French Total Diet Study. Food Chem Toxicol 50:2432-2449

63. Marín S, Pardo O, Baguena R, Font G, Yusà V (2017) Dietary exposure to trace elements and health risk assessment in the region of Valencia, Spain: a total diet study. Food Addit Contam Part A 34:228-240

64. Gardner FH (1953) The use of cobaltous chloride in the anemia associated with chronic renal disease. J Lab Clin Med 41:56-64

65. Rohn RJ, Bond WH, Klotz LJ (1953) The effect of cobalt-iron therapy in iron deficiency anemia in infants. J Indiana State Med Assoc 46:1253-1260

66. Paustenbach DJ, Tvermoes BE, Unice KM, Finley BL, Kerger BD (2013) A review of the health hazards posed by cobalt. Crit Rev Toxicol 43:316-362

67. McDowell LR (1989) Vitamins in animal and human nutrition, 2nd edn. lowa State University Press, Ames, pp 523-559

68. Yaman M (2014) Teucrium (Teucrium polium L.) as novel discovered hyperaccumulator for phytoextraction of $\mathrm{Ni}$ contaminated soils. Ekol 90:81-89

69. Ozen SA, Yaman M (2017) Examination of correlation between histidine, sulphur, cadmium and cobalt absorption by Morus L., Robinia pseudoacacia L., and Populus nigra L. Commun Soil Sci Plant Anal 48:1212-1220

70. Kukier UM, Peters CA, Chaney RL, Angle JS, Roseberg RJ (2004) The effect of $\mathrm{pH}$ on metal accumulation in two Alyssum species. J Environ Qual 33:2090-2102

71. Li Z, MacLaren RG, Metherell AK (2004) The availability of native and applied soil cobalt to ryegrass in relation to soil cobalt and manganese status and other soil properties. NZ J Agric Res 47:33-43

72. Yang $X$, Feng $Y, H e ~ Z$, Stoffella PJ (2005) Molecular mechanisms of heavy metal hyperaccumulation and phytoremediation. J Trace Element Med Biol 18:339-353

73. Williams LE, Pittman JK, Hall JL (2000) Emerging mechanisms for heavy metal transport in plants. Biochem Biophys Acta 1465:104-126
74. Morel M, Crouzet J, Gravot A, Auroy P, Leonhardt N, Vavasseur A, Richaud P (2009) AtHMA3, a P1B-ATPase allowing Cd/Zn/Co/ $\mathrm{Pb}$ vacuolar storage in Arabidopsis. Plant Physiol 149:894-904

75. Arguello JM, Eren E, Gonzalez- Guerrero M (2007) The structure and function of heavy metal transport $\mathrm{P}_{1 \mathrm{~B}}$-ATPases. Biometals 20:233-248

76. Rutherford JC, Cavet JS, Robinson NJ (1999) Cobalt dependent transcriptional switching by a dual effector MeR like protein regulates a cobalt exporting variant CPx type ATPases. J Biol Chem 274:25827-25832

77. Sarma H (2011) Metal hyperaccumulation in plants: a review focusing on phytoremediation technology. J Environ Sci Technol 2:118-138

78. Saaltink R, Griffioen J, Mol G, Birke M (2014) Geogenic and agricultural controls on the geochemical composition of European agricultural soils. J Soils Sediments 14:121-137

79. El-Sheekh MM, El-Naggar AH, Osman MEH, El-Mazaly E (2003) Effect of cobalt on growth, pigments and the photosynthetic electron transport in Monoraphidium minutum and Nitzchia perminuta. Braz J Plant Physiol 15:159-166

80. Parmar G, Chanda V (2005) Effects of mercury and chromium on peroxiodase and IAA oxidase enzymes in the seedlings of Phaseolus vulgaris. Turk J Biol 2:15-21

81. Jayakumar K, Jaleel CA, Vijayarengan P (2007) Changes in growth, biochemical constituents, and antioxidant potentials in radish (Raphanus sativus L.) under cobalt stress. Turk J Biol 31:127-136

82. Sree KS, Keresztes A, Mueller- Roeber B, Brandt R, Eberius M, Fischer W, Appenroth K-J (2015) Phytotoxicity of cobalt ions on the duckweed Lemna minor morphology, ion uptake, and starch accumulation. Chemosphere 131:149-156

83. Chatterjee J, Chatterjee C (2003) Management of phytotoxicity of cobalt in tomato by chemical measures. Plant Sci 164:793-801

84. Liu J, Reid RJ, Smith FA (2000) The mechanism of cobalt toxicity in mung beans. Physiol Plant 110:104-110

85. Zeid IM (2001) Responses of Phaseolus vulgaris to chromium and cobalt treatments. Biol Plant 44:111-115

86. Pandey N, Sharma CP (2001) Effect of heavy metals $\mathrm{Co}^{2+}, \mathrm{Ni}^{2+}$ and $\mathrm{Cd}^{2+}$ on growth and metabolism of cabbage. Plant Sci 163:753-758

87. Gopal R, Dube BK, Sinha P, Chatterjee C (2003) Cobalt toxicity effects on growth and metabolism of tomato. Commun Soil Sci Plant Anal 34:619-628

88. Emam AE, Gad N, Badran NM (2007) Effect of cobalt and nickel on plant growth, yield and flavonoid content of Hibiscus sabdariffa L. Aust J Basic Appl Sci 2:73-78

89. Mittal N, Sharma K, Oshin Kaur A (2017) Toxicity of metals such as iron, nickel and cobalt on seedlings of broad beans (Vicia faba L.). Biotechnology 3:809-810

90. Garba TS, Osemeahon AS, Mania HM, Barminas JT (2012) Ethylenediaminetetraacetate (EDTA) assisted phytoremediation of heavy metal contaminated soil by Eleusine indica L. Gearth. J Environ Chem Ecotoxicol 45:103-109

91. Boopathy R (2000) Factors limiting bioremediation technologies. Biol Technol 74:63-67

92. Verma S, Kuila A (2019) Bioremediation of heavy metals by microbial process. Environ Technol Innov 14:100369

93. Kumar A, Bisht BS, Joshi VD, Dhewa T (2011) Review on bioremediation of polluted environment a management tool. Int J Environ Sci 1:1079-1093

94. Pivetz BE (2001) Phytoremediation of contaminated soil and ground water at hazardous waste sites. US Environmental Protection Agency, Office of Research and Development, Office of Solid Waste and Emergency Response 
95. Jing $Y, H e Z$, Yang $X$ (2007) Role of soil rhizobacteria in phytoremediation of heavy metal contaminated soils. J Zhejiang Univ 8:192-207

96. Glick BR (2010) Using soil bacteria to facilitate phytoremediation. Biotechnol Adv 28:367-374

97. Hechmi N, Ben Aissa N, Abdenaceur H, Jedidi N (2015) Uptake and bioaccumulation of pentachlorophenol by emergent wetland plant Phragmites australis (Common Reed) in cadmium co-contaminated soil. Int J Phytoremed 17:109-116

98. Alkorta I, Becerril JM, Garbisu C (2010) Phytostabilization of metal contaminated soils. Rev Environ Health 25:135-146

99. Bolan NS, Park JH, Robinson B, Naidu R, Huh KY (2011) Phytostabilization: a green approach to contaminant containment. Advances in agronomy, vol 112. Academic Press, London, pp 145-204

100. Van Herreweghe S, Swennen R, Cappuyns V, Vandecasteele C (2002) Chemical associations of heavy metals and metalloids in contaminated soils near former ore treatment plants: a differentiated approach with emphasis on pHstat-leaching. J Geochem Explor 76:113-138

101. McGrath SP, Zhao FJ (2003) Phytoextraction of metals and metalloids from contaminated soils. Curr Opinion Biotechnol 14:277-282

102. Malik M, Chaney RL, Brewer EP, Li YM, Angle JS (2000) Phytoextraction of soil cobalt using hyperaccumulator plants. Int J Phytoremed 2:319-329
103. Woodard TL, Thomas RJ, Xing B (2003) Potential for phytoextraction of cobalt by tomato. Commun Soil Sci Plant Anal 34:645-654

104. Dushenkov V, Kumar PN, Motto H, Raskin I (1995) Rhizofiltration: the use of plants to remove heavy metals from aqueous streams. Environ Sci Technol 29:1239-1245

105. Kushwaha A, Hans N, Kumar S, Rani R (2018) A critical review on speciation, mobilization and toxicity of lead in soil-microbeplant system and bioremediation strategies. Ecotoxicol Environ Saf 147:1035-1045

106. Kamel HA, Eskander SB, Aly MAS (2007) Physiological response of Epipremnum aureum for cobalt-60 and cesium-137 translocation and rhizofiltration. Int J Phytoremed 9:403-417

107. Prajapati SK, Meravi N, Singh S (2012) Phytoremediation of chromium and cobalt using Pistia stratiotes: a sustainable approach. Proc Int Acad Ecol Environ Sci 2:136

Publisher's Note Springer Nature remains neutral with regard to jurisdictional claims in published maps and institutional affiliations. 